\title{
The EU external policy and the 2015-2018 refugee relocation system in the light of historical institutionalism ${ }^{1}$
}

\section{Introduction}

\section{Method and methodology}

The combination of EU external policy and the refugee crisis in Europe has not been much scientifically explored, in particular in the light of historical institutionalism. While examining the topic, the author refers to his research output which he has refined, corrected and updated. The topic is particularly important considering rapid changes in the EU itself, since issues valid at a given time have been no longer relevant a month later.

Publications that deserved special attention in this article include: Kryzys i zaburzona dynamika Unii Europejskiej, Wydawnictwo Elipsa, Warsaw 2013, Unia Europejska w procesie zmiany. Jak przeszłość wpływa na przyszłość, in: 10 lat członkostwa Polski w Unii Europejskiej. Ocena i perspektywy, eds. E. Latoszek, A. Stępniak, A. Kłos, M. Krzemiński, Wydawnictwo Uniwersytetu Gdańskiego, Gdańsk 2014 and Wzrost antyimigracyjnego radykalizmu i eurosceptycyzmu jako wyzwanie dla przyszłości Unii Europejskiej, in: Uchodźcy w Europie - uwarunkowania, istota, następstwa, eds. K. A. Wojtaszczyk, J. Szymańska, Wydawnictwo ASPRA-JR, Warsaw $2016^{2}$.

\section{Epistemic grounds}

\subsection{Historical institutionalism paradigm}

Historical institutionalism refers to interactions between EU integration actors, interactions analysed in retrospect in the light of policy papers. The time factor is particularly important, since it enables to follow the institutional process defined by EU norms, procedures and integration rules and their sequential impact on favoured treatment or disavowing of integration visions, preferences, needs and interests (Czachór, 2014, pp. 29-45).

${ }^{1}$ Publikacja została zrealizowana przy wsparciu finansowym Komisji Europejskiej w ramach projektu Jean Monnet Centre of Excellence - EU external actions in the contested global order - (In) coherence, (dis)continuity, resilience (nr 599622-EPP-1-2018-1-PL-EPPJMO-CoE). Wyłączną odpowiedzialność za treść publikacji ponosi jej autor.

${ }^{2}$ Since the publications are referred to in the main text of the article, they are not listed in the bibliography. 
It is assumed that historically the EU institutionality has formed a structure of collaboration models and forms, thus creating a mechanism to reach consensus and compromise or resolve conflicts and disputes, for instance the conflict over the relocation of refugees (migrants) (Trzaskowski, 2005, pp. 40-48).

Being interparadigmatic, the institutional and historical analysis combines crucial components of neofunctionalism and intergovernmental approach. The inevitability is an inherent in the above in terms of consequences of previous political obligations and institutional choices. Moreover, previous decisions form a functional base for new "historically bound" institutional and political acts. In the same vain as the spill over mechanism, they lead to further interdependent integration steps and related to them tangible and intangible entities. It can be compared to an arithmetic progression, in which successive decisions result from adding new elements (motives, grounds, specific norms) to a preceding decision. This produces complex decisions which comprise the old and the new (Czachór, 2013, pp. 239-241).

Since the Treaty on European Union adopted in Maastricht has confirmed supranational powers of EU institutions, these institutions have been independent in using them. The sovereignty of EU institutions does not differ from the national one. Moreover, they remind me of how easy it is to resign from previously adopted EU extra-governmental methods (path-dependency) to manage short-term national interests (De Donno, 2011).

Considering the above, the refugee relocation system proposed and introduced in 2015-2018 has confirmed the above stated research objectives. Firstly, the EU Commission and the Council decided on mandatory relocation. Then, the Council adopted an act which regulated the issue. Under the pressure (chiefly from Germany), Member States initially agreed to the decisions which they later started to undermine. Today, the European Union struggles with consequences of its own previous actions.

\section{Notional grounds - basic notions and scientific categories}

\subsection{Migration}

Migrations have accompanied men from the beginning of human history and, to a large extent, have shaped the world that we know today. They are hardly predictable and controllable, and since migrations occur in time and space, they differ in terms of their causes, duration, distances, modes, and their organisation and ethnic setups. They are more unsystematic and variable than socio-demographic phenomena, especially when underlined by hardly predictable political or economic changes. In recent years, migrations have become some of the most important political and social challenges for the contemporary world. Due to their massive scale, broad presence, dynamics and complexity, as well as tensions and conflicts they produce, migrations have acquired a peculiar character. They evolved from a distant and marginal phenomenon to become a paramount challenge for external and internal state policies (mainly in the EU), and attracted much attention and emotions of the general public (Zając, 2008, p. 5 et seq.) 


\subsection{Refugees}

Seeking refuge is one of major issues faced by the contemporary international community. As mentioned above, the influx of refugees has not started yesterday. However, the process has become more intensive recently. In the past, tensions between different cultural and ethnic groups and between human rights and state authority often led to wars, persecution, displacement of people and refuge. Today, the refugee drama can be seen all over the world. Thus, many refugees have been going through the trauma for years, and often it is the only life they know (Zając, 2008, p. 5 et seq.).

"Refugees" are all people forced by external circumstances to leave their home country. We can distinguish two groups of circumstances leading to the phenomenon: man-made and natural disasters. The former includes primarily military conflicts and persecution, and the latter natural disasters, such as drought, earthquake, etc. (Wierzbicki, 1993, p. 25 et seq.)

International law has adopted a definition of refugee from the 1951 Refugee Convention. The definition is based on three elements: stay beyond the territory one's home country; real threat of persecution on the grounds of race, religion, nationality, membership of a specific social group and political views; and the lack of protection offered in one's home country (Wierzbicki, 1993, p. 25 et seq.). Persecution, which is a basis to apply for the refugee status, may result from actions taken by state or nonstate actors.

\subsection{Relevant categories and notions used in EU policy papers}

The first term is "temporary measures," such measures include all activities and decisions pertaining to international protection, chiefly in relation to Italy and Greece, to support Member States in extraordinary situations caused by sudden influx of citizens from third states. EU regulations use the term "international protection" as a measure which leads to the refugee status and the status of a person in need of protection. Then, "relocation" refer to the transfer of a migrant (refugee) from the territory of one Member State to another Member State. The "country of relocation" means a state which becomes responsible for processing applications filed to obtain international protection after applicants are relocated to the territory of a given Member State (Czachór, 2016, p. 234 et seq.).

\section{Chronology of historical institutionalism}

\section{The year of 2015}

The migration crisis in the Mediterranean Sea Region forced EU institutions to recognise migration in the region as an extraordinary situation and call for solidarity 
support to frontline Member States. On $20^{\text {th }}$ April 2015, at a joint meeting of foreign and interior ministers, the European Commission presented a ten-point action plan of immediate actions in response to the crisis situation, including the obligation to consider options for the emergency relocation mechanism. During their meeting of $23^{\text {rd }}$ April 2015, the European Council decided to strengthen internal solidarity and responsibility. It also undertook to increase assistance to frontline Member States in emergency situations and consider the possibility of voluntary emergency relocation between Member States and the deployment of EASO teams (European Asylum Support Office) in frontline Member States to process international protection applications, including fingerprint registration.

In their resolution of $28^{\text {th }}$ April 2015, the European Parliament repeated their reaction to the tragic incidents on the Mediterranean Sea by stating that EU actions need to be based on solidarity and just division of responsibility, and the EU should increase its support for Member States receiving the largest number of refugees and applications for international protection.

On $13^{\text {th }}$ May 2015, the European Commission proposed to adopt the European Migration Programme and its first implementation package, including the relocation of 40 thousand people from Greece and Italy, resettlement 20 thou. people from beyond the EU, action plan to prevent trafficking in migrants, and to triple funds and equipment used in search and rescue operations at sea. Several days later, on $27^{\text {th }}$ May 2015, the European Commission adopted a motion calling for the Council decision to introduce temporary protection measures for Italy and Greece. This provided for a mechanism to react to emergency situations, as foreseen in Article 78.3 of the Treaty on the Functioning of the European Union (TFEU) (Europejski Program, 2015, pp. 2-4).

During their meeting of $25^{\text {th }}$ and $26^{\text {th }}$ June 2015, the European Council decided to deal with three key issues in parallel: relocation, readmission, and the cooperation with origin and transit countries. Considering the current emergency situation and the obligation to enhance solidarity and responsibility, the European Council primarily agreed to temporary and emergency relocation of migrants from Italy and Greece to other Member States. During initial two years, the process involved 40 thousand people in need of international protection. The relocation process was expected to involve all Member States (Conclusions of the European Council, 2015, pp. 2-3).

On $20^{\text {th }}$ July 2015, a consensus was reached to reflect a particular position of specific Member States followed by a resolution adopted by representatives of Member States present in the Council on the relocation from Greece and Italy of 40 thou. people in need of international protection (Wniosek, 2015, pp. 2-3).

On $14^{\text {th }}$ September 2015, the EU council adopted a decision establishing the temporary and emergency relocation mechanism to relocate people in need of international protection from Italy and Greece to other Member States (Decyzja, 2015, pp. 2-3). Due to the unprecedented influx of migrants to Italy and Greece and the shift of migration from middle to eastern parts of the Mediterranean Sea Region as well as to Western Balcans and Hungary. On $9^{\text {th }}$ September 2015, the European Commission presented the second relocation scheme. The scheme included the following projects: relocation of additional 120 thou. asylum seekers from EU Member States 
particularly exposed to migration, permanent emergency relocation mechanism, European hazardous countries list, readmission action plan, readmission guide, and the EU Trust Fund for Africa of total budget EUR 1.8 billion (Migracje: plan działania, 2016).

On $22^{\text {nd }}$ September 2015, the Council adopted yet another decision on migration. The decision included the obligation to relocate 120 thou. migrants to other Member States (Decyzja, 2015).

\section{The year of 2016}

On $7^{\text {th }}$ March 2016, a summit of the European Council was held involving the Turkish Prime Minister to discuss solutions to the migration crisis. The meeting signed a joint declaration and decided that Turkey would try to stop the flow of migrants via its territory to Europe. In exchange, Turkey was reassured that accession negotiations would be expedited significantly and visa procedures liberalised. Additionally, Turkey was to receive a major financial support. Talks on the matter continued during the session of the European Council on 17-18 March. The session was successful, since an agreement was reached with Turkey to stop the flow migrants. The agreement was based on the following:

- Turkey agreed that all irregular migrants intercepted in Greece are to be returned to Turkey;

- EU undertook to accept Syrian refugees coming directly from camps in Turkey;

- EU agreed to open new accession negotiation chapters;

- Turkey was to receive EU funds to stop the migration and provide better conditions for migrants in Turkey (ca 6 billion euros); and

- Visa procedures for Turkish citizens to be liberalised faster.

On $7^{\text {th }}$ June 2016, the European Commission and the High Representative initiated a migration partnership with the aim to tighten collaboration with countries of origin and transit, in particular in Africa, for better joint migration control (Czachór, 2016, p. 234 et seq.). After agreement with Turkey was reached, on $29^{\text {th }}$ September 2016 , the EU Council decided on the relocation of 54,000 Syrian migrants from Turkey to the EU (Decyzja, 2016).

Due to the urgent need to support Greece and Italy, in their conclusions of $20^{\text {th }}$ and $21^{\text {st }}$ October, the European Council called again to expedite the implementation of relocation and resettlement schemes. On $15^{\text {th }}$ December the same year, the Council approved a joint action plan that implemented decisions included in the EU-Turkey statement on 3,000 people monthly relocation rate for Greece and called for further effort to expedite relocation, in particular unaccompanied minors.

In 2016, the European Commission adopted the First Report on Relocation and Resettlement. The Second, Third, Fourth, Fifth, Sixth, Seventh and Eighth Reports were adopted respectively on $12^{\text {th }}$ April, $18^{\text {th }}$ May, $15^{\text {th }}$ June, $13^{\text {th }} \mathrm{July,} 28^{\text {th }}$ September, $9^{\text {th }}$ November, and $8^{\text {th }}$ December 2016.

On $15^{\text {th }}$ February 2016, prime ministers of the Visegrad Group, together with representatives of Bulgaria and Macedonia, adopted a Joint Migration Declaration. In it 
they emphasised that actions taken to solve the refugee crisis should be implemented at the EU level. This, however, stood in contradiction to the actual steps taken by group members. Firstly, without consultation with other EU Member States, Hungary started to build a wall not only on the external EU border with Serbia, but also on the internal one with Croatia. Secondly, Poland and Hungary assigned only a few experts to the European Asylum Support Office (EASO) and only a few border guards to FRONTEX. Moreover, the Declaration stated that actions by FRONTEX should be based on "appropriate balance between EU powers and sovereign competences of Member States." The latter was interpreted as an objection to empower FRONTEX, e.g. their independent operation on territories of Member States, if needed. Thirdly, all countries members of the group objected to the migrant relocation system developed at the EU level (Grupa, 2016).

On $24^{\text {th }}$ February 2016, Prime Minister V. Orbán declared that the Hungarian Government would organise a referendum on EU mandatory migrant quotas. The referendum question was: "Do you want to allow the European Union to mandate the resettlement of non-Hungarian citizens to Hungary without the approval of the National Assembly?" Then, in early March, the Hungarian Minister of Internal Affairs S. Pintér announced the state of crisis due in connection with mass migration.

An example of the attitude the Polish government has to refugees is the resolution of the lower house of the Polish Parliament (the Sejm) of $1^{\text {st }}$ April 2016 regarding the Poland's immigration policy. It reads: "The Sejm objects to the decision of the European Council of $22^{\text {nd }}$ September 2015 on relocation of 120 thou. refugees and support given to the decision by the then Polish Government despite a contradictory position of Romania and other states members of the Visegrad Group. The Sejm calls the Polish Government to apply strictly the domestic criteria of the country's refugee policy, a policy which extends particular care of single women, children, multi-child families and religious minorities. The Sejm expressly objects to any attempts to establish permanent EU refugee or migrant allocation mechanisms. Refugee and immigration policy instruments should remain at the discretion of Poland. It is particularly important due to the growing social tensions caused by the influx of migrants from the Middle East to Europe. The Sejm fully approves the application and funding of humanitarian aid in locations of military conflicts and neighbouring countries" (Uchwaty, 2015).

\section{The year of 2017}

In 2017, the European Commission adopted further progress reports on emergency relocation and resettlement schemes. In the reports, the Commission concluded that the progress made by Member States was insufficient to meet the targets. According to the report, as of $10^{\text {th }}$ April 2017, 15,492 people had been relocated to 21 countries. Some Member States and Associated Countries fulfilled their targets (Estonia, Ireland, Netherlands, Finland, Sweden, United Kingdom, Iceland, Liechtenstein and Switzerland). Although further states joined in and contributed to the EU relocation and resettlement scheme, their share remained uneven. Nine 
Member States (Bulgaria, Cyprus, Greece, Croatia, Malta, Poland, Romania, Slovakia and Slovenia) did not even start to resettle people under EU schemes (Jedenaste, 2017).

In December 2017, the European Commission adopted a recommendation for state leaders to expedite actions taken to ensure speedy progress of the reform of the Community asylum system, strengthen partnership with third countries, enable new paths for legal migration to Europe and secure funding for the future (Polityczny, 2017). Thus, the Commission appealed to:

- the European Council to restore the debate on the reform of the Dublin System to make relocation mandatory in a serious crisis situation only, whereas in difficult situations relocation should be decided by Member States individually;

- expedite the formulation of conclusions on the European Asylum Support Office and Eurodac to ensure operational basis for the overhauled asylum system;

- provide Member States with immediate support as regards the protection of their external borders. The EU needs to make the European Border and Coast Guard Agency operational to conclude of the establishing of an efficient EU external border management system;

- full implementation of the EU-Turkey statement through the EU Facility for Refugees in Turkey;

- strengthen the strategic partnership with the African Union and its member states, and implement the first series of projects under the EU external investment plan and to replenish financial resources for the North African segment of the EU Emergency Trust Fund for Africa; and

- strengthen the European Border and Coast Guard Agency.

The European Commission informed the public that from 2015 on the EU would increase funding for the Asylum, Migration and Integration Fund and Internal Security Fund by nearly 75 percent. In parallel, funding designated for other EU agencies increased as well. Member States leaders were to consider how to secure funding for the external dimension of the migration policy and fast mobilisation of resources to eliminate primary causes of migration and ensure protection for refugees and migrants. Another multiannual financial framework (7-year period) should reflect experience of the previous three years and provide for flexible instruments for efficient response to future migration challenges (Polityczny, 2017).

During another session on Migration and Relocation Schemes, EU leaders discussed internal and external dimensions of the EU policy. They also defined successful measures and failures during the previous two years, as well as they discussed ways of fine-tuning UE policies (Konkluzje, 2017). The debate focused on the following issues: preventing of mass inflow of migrants to external EU borders, eliminating of primary migration causes, and overcoming of internal bottlenecks that prevent political progress. The discussion was to pave the way to an agreement on the reform of the Asylum System by June 2018. D. Tusk, the President of the European Council, noticed: "although mandatory quotas remain controversial, the debate become less heated. For this reason, it is worth to continue the discussion on the matter. Will the compromise be possible? It seems very difficult, but we need to try our best" (Wystapienie, 2017). 


\section{The year of 2018}

The European Commission confirmed that in the first months of 2018 the number of illegal migrants dropped. ${ }^{2}$ The Commission also concluded that comprehensive actions were taken to rescue lives and eliminate the main cause of migration, protect external EU borders and strengthen cooperation with international partners. Moreover, the Commission admitted that the situation was still delicate and further effort was necessary, in particular to increase funding available for Members States and the EU to address challenges related to migration efficiently. The cooperation between the $A U, E U$ and UN had produced initial results, although these were not particularly spectacular. It was necessary to increase and expedite measures related to resettlement, border management and legal migration, in particular relocation from Africa and Turkey (Europejski, 2018).

The EU Emergency Trust Fund for Africa still plays a key role to eliminate the main causes of migration, provide protection to migrants and refugees, and combat illegal migration and trafficking in people. The Fund supports 147 programmes of total budget EUR 2.5 billion. The programmes are implemented in the area of Sahel and Lake Chad, Horn of Africa and North Africa. Nevertheless, still over EUR 1 billion is needed to implement the most important measures (Europejski, 2018).

In 2018, it was decided that technical and operational strategies were need to develop the European integrated border management. Members States should immediately cover the shortages of experts and technical equipment in the European Border and Coast Guard Agency. It was also necessary to resettle refugees from Libya under the Emergency Transit Mechanism.

\section{Conclusion}

The migration crisis (caused by massive inflow of migrants) is a serious dysfunctional, cultural, social, economic and political phenomenon that involves a series of risks and threats for Europe and the European Union. It is an unprecedented challenge faced by the European Union and its internal and external policies. For this reason, the primary factor underlying the crisis is a political conflict between Member States, the EU and its external environment. Unfortunately, however, the European Commission and the Parliament in consultation with the Council of the EU and the European Council turned out to be incapable to reach a consensus and develop crisis prevention measures that could stop the influx of migrants to the territory of the EU, and solve the problem of migrants who had already arrived to the EU in the previous several months (Czachór, Jaskulski, 2016, pp. 7-10).

The migration crisis is yet another existential crisis that has bothered the European Union in the past several years. It has coincided with the following:

- Financial crisis - related to indebtedness that spilled from the Euro Zone to the rest of the Union; and

- Crisis related to Brexit and growing Euroscepticism.

2 According to Eurostat, in 2017, 28 EU Members States provided protection to 538,000 persons who applied for asylum. It is $25 \%$ lower that the same figure for 2016 . 
This deepens difficulties in decision-making in the entire EU system. Moreover, it is a serious threat to the Internal Market and its four freedoms (i.e. movement of people, goods, services and capital) and the Schengen Area.

The main political issues related to the migration crisis include the cost generated by migrants coming to the EU. The cost comprises registration, basic financial aid, accommodation and meals, health care, remuneration for administration personnel, logistics, including transfer of migrants between territories of Member States, and security of migrant facilities. Since the registration and the processing of asylum/refugee applications is lengthy, the cost becomes much larger if compared to a regular inflow of migrants. Moreover, rejected applications generate additional cost related to the readmission of immigrants, whereas protection measures applied generate cost related to subsistence and integration of migrants under protection schemes (Czachór, Jaskulski, 2016, pp. 7-10).

The experience so far has shown that Member States attracting the largest number of migrants incur enormous cost related to temporary solutions, since existing infrastructure and human resources are insufficient. For this reason, while presenting their proposals, the European Commission pointed to the need for financial support from the EU budget to Member States that receive people under relocation schemes.

In general, while analysing externalities of the migration crisis, we may conclude that serious consequences of the global economic crisis are an excessive burden for Member State budgets. On top of this, additional cost is generated by a lengthy stay of migrants in those countries. People who are accepted and covered by protection schemes require additional funding to be allocated to integrate them with societies and prepare them to seek jobs in Member States. Later, based on provisions of the international law, migrants will try to unify with their families. This may translate into an additional pressure on mid-term Member State budget expenditure. Our experience so far has shown that migrants, including younger generations, hardly integrate with local communities. This produces a pressure on welfare system in particular countries (Czachór, Jaskulski, 2016, pp. 7-10).

Although some social and cultural consequences of the migration crisis can already be seen, many of them will only appear after a longer period. Firstly, we may observe a major increase in radical anti-immigration attitudes in Member States. It is also related to Euroscepticism, since the EU is perceived as the main perpetrator of the current crisis. Secondly, migration from North Africa and Middle East is perceived as a source of potential threat of terrorism. This, at the same time, boosts anti-EU trends, regardless whether the threat is real or not. Thirdly, such attitudes increasingly often lead to protests and sometimes violence. Thus, they extend beyond merely verbal expression of dissatisfaction of western societies. Undoubtedly, the processes and attitudes will solidify and they will further reduce trust and support for the European Union in the years to come (Czachór, Jaskulski, 2016, pp. 7-10).

\section{Bibliography/scientific inspiration}

Back to Schengen - A Roadmap (2016), Communication from the Commission to the European Parliament, The European Council and the Council, COM (2016) 120 final, Brussels, 4.3.2016. 
Czachór Z., Jaskulski A. (2016), Problem kryzysu migracyjnego w Europie/Unii Europejskiej. Stanowisko Polski z punktu widzenia dlugofalowego interesu narodowego oraz polskiej pozycji w Unii Europejskiej, Ekspertyza dla Instytutu Obywatelskiego, Warsaw.

Decyzja Rady (UE) 2015/1523 z dnia 14 września 2015 r. ustanawiająca środki tymczasowe w obszarze ochrony międzynarodowej na rzecz Włoch i Grecji (2015), Dziennik Urzędowy Unii Europejskiej, L 239.

Decyzja Rady (UE) 2015/1601 z dnia 22 września 2015 r. ustanawiająca środki tymczasowe w obszarze ochrony międzynarodowej na rzecz Włoch i Grecji (2015), Dziennik Urzędowy Unii Europejskiej, L 248.

Decyzja Rady (UE) 2016/1754 z dnia 29 września 2016 r. zmieniająca decyzję (UE) 2015/1601 ustanawiająca środki tymczasowe w obszarze ochrony międzynarodowej na rzecz Włoch $i$ Grecji (2016), Dziennik Urzędowy Unii Europejskiej, L 268.

De Donno M. (2011), The Theories of the European Integration. A Historical Institutionalist Analysis of the European Integration. Why European Institutions Matter, "Political Science", 154, Fall, www.academia.edu, 11.11.2013.

Dobrowolska-Polak J. (2016), Kryzys imigracyjny - Europa w oku cyklonu?, "Biuletyn Instytutu Zachodniego", Seria Specjalna: "Uchodźcy w Europie”, no. 219.

Duński parlament zaostrzy przepisy dotyczace uchodźców, 27.01.2016, http://www.euractiv.pl/ politykawewnetrzna/artykul/duski-parlament-zaostrzy-przepisy-dotyczce-uchodcow007907?newsletter=3216, 29.02.2016.

Europejski program w zakresie migracji: Ciagty postęp wymaga nieustannych starań (2018), Komunikat prasowy, Komisja Europejska, Brussels, 14 March 2018.

Europejski program w zakresie migracji (2015), Komunikat Komisji do Parlamentu Europejskiego, Rady, Europejskiego Komitetu Ekonomiczno-Społecznego i Komitetu Regionów, Brussels, 13.5.2015, COM (2015) 240 final.

Francja nie przyjmie większej liczby uchodźców, 19.01.2016, http://www.euractiv.pl/politykawewnetrzna/artykul/francja-nie-przyjmie-wikszej-liczby-uchodcow-008003?newsletter=3216, 16.02.2016.

FRAN Quarterly - Number of illegal border-crossings at record high in Q4, 10.03.2016, http://frontex.europa.eu/pressroom, 21.02.2016.

Grupa Wyszehradzka wzywa do uszczelnienia granic, 21.01.2016, http://www.euractiv.pl/rozszerzenie/artykul, 26.02.2016.

Istnieja poważne niedociagnięcia w zarządzaniu granica zewnętrzna w Grecji, 11.01.2016, http:// ec.europa.eu/polska/news/160127_grecja_pl.htm, 13.01.2016.

Jaskulski A. (2012), Zmiana równowagi międzyinstytucjonalnej w Unii Europejskiej po traktacie nicejskim, praca doktorska, Poznań.

Jedenaste sprawozdanie z postępów w realizacji unijnych programów relokacji i przesiedleń $w$ sytuacjach nadzwyczajnych, Komisja Europejska, Komunikat prasowy, Brussels, 12 April 2017.

KE: 54 tys. Syryjczyków z Turcji zamiast relokacji, 22.03.2016, http://www.euractiv.pl/instytucje, 24.03.2016.

Konkluzje Rady Europejskiej 25 i 26 czerwca 2015 r., EUCO 22/15 Brussels, 26 June 2015.

Konkluzje Rady Europejskiej 14 grudnia 2017 r., EUCO 19/17, Brussels, 14 December 2017.

Konwencja dotycząca statusu uchodźców, Genewa 28 July 1951, Dz. U. of 20 December 1991, no. 119 , items 515 and 516.

Migracje: plan dziatania, 14.01.2016, http://ec.europa.eu/polska/news/160113_kryzys_pl.htm, 14.01.2016.

Niemcy zmieniaja prawo migracyjne, 16.02.2016, http://www.euractiv.pl/politykawewnetrzna/arty$\mathrm{kul} /$ niemcy-zmieniaj-prawo-migracyjne-007926?newsletter=3216, 16.02.2016. 
Petersen T. (2016), Willkommens-kultur?, "Die Politische Meinung”, no. 534, September/October. Pieniądze za odrzuconych uchodźców, 13.02.2016, http://www.euractiv.pl/politykawewnetrzna/artykul/austria-kurz-007956?newsletter=3216, 13.02.2016.

Pierson P. (1998), The Path to European Integration: A Historical-Institutionalist Analysis, in: European Integration and Supranational Governance, eds. W. Sandholtz, A. Stone Sweet, Palgrave Macmillan, Oxford.

Polityczny plan działania, Komisja Europejska, Komunikat prasowy, Brussels, 7 December 2017.

Program $w$ zakresie migracji, 10.02.1016, http://ec.europa.eu/polska/news/160210_migracje_ pl.htm, 10.02.2016.

Reakcja na presje migracyjna. Kalendarium, 10.02.2018, http://www.consilium.europa.eu/en/policies/migratory-pressures/history-migratory-pressures/, 10.02.2018.

Risk Analysis for 2008, Reference number: 2671/2018, Risk Analysis Unit Frontex, Warsaw, February 2018.

Savidan P. (2012), Wielokulturowść, Oficyna Naukowa, Warsaw.

The assimilation of terrorists and foreigners is a serious mistake which does not match reality. Interview with Gilles de Kerchove, EU Counter-Terrorism Coordinator, European Interview no. 90, Foundation Robert Schuman, 14 March 2016.

Trzaskowski R. (2005), Dynamika reformy systemu podejmowania decyzji w Unii Europejskiej, Wydawnictwo Prawo i Praktyka Gospodarcza, Warsaw.

Tusk do imigrantów: Nie przyjeżdżajcie, 03.03.2015, http://www.euractiv.pl/politykawewnetrzna, 5.03.2016.

UE zaostrza kontrolę swoich granic zewnętrznych, 12.02.2016, http://www.euractiv.pl/instytucje/artykul/ue-nasila-kontrol-swoich-granic-zewntrznych-007780, 12.02.2016.

Unia Europejska pomoże uchodźcom w Turcji, 11.01.2016, http://www.euractiv.pl/polityka-zagraniczna/artykul/unia-europejska-pomoe-uchodcom-w-turcji-007957?newsletter=3216, 11.01.2016.

Weber M. (2016), Europaeischer Spaltpilz?, „Die Politische Meinung”, no. 534, September/October.

Wierzbicki B. (1993), Uchodźcy w prawie międzynarodowym, Wydawnictwo Naukowe PWN, Warsaw.

Wild F. (2016), Readmission agreements of the European Union - A policy instrument with lacking incentives, CIFE Policy Paper no. 28, January 18.

Wniosek dotyczacy rozporzadzenia Parlamentu Europejskiego i Rady ustanawiajacego kryzysowy mechanizm relokacji i zmieniajacy rozporzadzenie Parlamentu Europejskiego i Rady (UE) nr 604/2013 z dnia 26 czerwca 2013 r. w sprawie ustanowienia kryteriów i mechanizmów ustalania państwa członkowskiego odpowiedzialnego za rozpatrzenie wniosku o udzielenie ochrony międzynarodowej złożonego $w$ jednym z państw członkowskich przez obywatela państwa trzeciego lub bezpaństwowca (COM(2015) 450 final), Brussels 9.09.2015.

Wystapienie Donalda Tuska po posiedzeniach Rady Europejskiej (14-15 December 2017), Brussels 15 December 2017.

Zając K. (2008), Uchodźstwo jako problem międzynarodowy. Działania Unii Europejskiej na rzecz uchodźców, Praca magisterska napisana pod kierunkiem prof. dr. hab. Zbigniewa Czachóra, Uniwersytet im. Adama Mickiewicza, Wydział Nauk Społecznych, Instytut Nauk Politycznych i Dziennikarstwa, Collegium Polonicum, Słubice.

\section{Summary}

The main research objective of the text is to analyse the refugee relocation system in the light of historical institutionalism in 2015-2018. Historical institutionalism refers to the interaction between European integration actors in the European Union system, analysed in retrospect 
from a documentary perspective. The time factor is particularly important, since it enables to follow the institutional process defined by EU norms, procedures and integration rules and their sequential impact on favoured treatment or disavowing of integration visions, preferences, needs and interests.

In view of the above, the refugee relocation system proposed and introduced in the period 2015-2018 confirms the above research assumption that the political decision on relocation made by the European Commission and the European Council resulted in a relevant legal act adopted by the EU Council to regulate the issue. Although under the pressure of the situation Member States agreed, some of them began to contest the decisions later.

Key words: refugee relocation system, historical institutionalism, 2015-2018 period, political decisions on mandatory relocation, situational pressure

\section{Polityka zewnętrzna Unii Europejskiej a system relokacji uchodźców 2015-2018 w świetle teorii instytucjonalizmu historycznego}

\section{Streszczenie}

Głównym celem badawczym tekstu jest analiza systemu relokacji uchodźców w świetle teorii instytucjonalizmu historycznego rozpatrywana w przedziale czasowym 2015-2017. Zastosowany tu instytucjonalizm zwany historycznym, odwołuje się do interakcji pomiędzy aktorami integracji europejskiej w systemie Unii Europejskiej, analizowanych z wykorzystaniem perspektywy dokumentalnej i retrospektywnej. Upływający czas ma tu istotne znaczenie, gdyż pozwala na prześledzenie procesu aktywności instytucji rozumianych także jako normy, procedury i zasady integracji w systemie UE oraz ich sekwencyjnego wpływu na faworyzowanie lub dezawuowanie określonych wizji, preferencji, potrzeb i interesów integracyjnych.

Z uwagi na powyższe system relokacji uchodźców zaproponowany i wprowadzony w okresie 2015-2018 potwierdza powyższe założenie badawcze, że to najpierw Komisja Europejska i Rada Europejska podjęły decyzje polityczne o obowiązkowej relokacji, po czym Rada UE ustanowiła w tym zakresie akt prawny, który tę kwestię unormował. Państwa członkowskie pod wpływem presji sytuacji zgodziły się na te decyzje, po czym część z nich zaczęła je kontestować.

Słowa kluczowe: system relokacji uchodźców, teoria instytucjonalizmu historycznego, przedział czasowy 2015-2018, decyzje polityczne o obowiązkowej relokacji, presja sytuacji 